\title{
Carnets
}

Revue électronique d'études françaises de l'APEF

Première Série - 4 Numéro Spécial | 2012

Invasions \& Évasions

\section{Napoleão Bonaparte e Portugal. Patriotismo, Revolução e Memória Política da Resistência}

Ana Cristina Araújo

\section{CpenEdition}

1 Journals

\section{Edição electrónica}

URL: http://journals.openedition.org/carnets/7215

DOI: $10.4000 /$ carnets. 7215

ISSN: 1646-7698

\section{Editora}

APEF

Edição impressa

Data de publição: 1 Junho 2012

Paginação: 13-28

\section{Refêrencia eletrónica}

Ana Cristina Araújo, « Napoleão Bonaparte e Portugal. Patriotismo, Revolução e Memória Política da Resistência », Carnets [Online], Première Série - 4 Numéro Spécial | 2012, posto online no dia 23 junho 2018, consultado o 01 maio 2019. URL : http://journals.openedition.org/carnets/7215; DOI : 10.4000/ carnets. 7215

\section{(c) (i) (8)}

Carnets est mis à disposition selon les termes de la licence Creative Commons - Atribution - Pas d'utilisation commerciale 4.0 International. 


\title{
NAPOLEÃO BONAPARTE E PORTUGAL. \\ Patriotismo e memórias da resistência
}

Ana Cristina AraúJo

Universidade de Coimbra

araujo.anacris@sapo.pt

\begin{abstract}
Resumo
Portugal teve o seu "momento Napoleão". Antes da ocupação francesa, o príncipe regente D. João e destacadas figuras da Corte receberam o alto grau da Legião de Honra e, em 1808, na ausência da família real, um grupo de cidadãos suplicou ao Imperador a outorga de uma Constituição e a adopção do Código de Direito Civil (1804). Os episódios que envolveram a acção dos 'afrancesados' e a mobilização da resistência - das elites e do povo - mostram que a aspiração de mudança política e a luta pela independência exprimem diferentes acepções de patriotismo.
\end{abstract}

\section{Abstract}

Portugal had its "Napoleonic moment". Before French occupation, the Regent Prince D. João and other prominent figures of the Court received the high distinction of the Legion of Honor and, in 1808, during the absence of the royal family, a group of citizens demanded the grant of a Constitution from the Emperor and the adoption of the Civil Code (1804). The episodes surrounding the action of the 'afrancesados' and the mobilization of resistance - both the elites and the people - show that the aspiration for political change and the fight for independence express different forms of patriotism.

Palavras-chave: emigração, constituição, patriotismo, guerra peninsular.

Keywords: emigration, constitution, patriotism, peninsular war. 
Portugal teve o seu "momento Napoleão". Na acepção em que John Pocock utiliza a expressão "momento Maquiavel" para exprimir o ressurgimento e o sentido do republicanismo cívico moderno (Pocock,1975), o "momento Napoleão" de que falamos corresponde a um modus civis cosmopolita e ilustrado que se consubstancia numa precisa aspiração de mudança constitucional, portadora de valores antigos e modernos, formulada em oposição ao Antigo Regime e marcada pelo horizonte de expectativa próximo de integração de Portugal no império continental napoleónico.

Como nota preliminar do cenário político-constitucional arquitectado em 1808, convém precisar de que modo é que a França pontuou a conjuntura portuguesa que antecedeu a retirada da casa reinante de Bragança para o Brasil e a ocupação francoespanhola do reino de Portugal, em Novembro de1807.

\section{Propaganda Republicana, Emigração Política e Diplomacia de Guerra}

A influência da política internacional francesa revela-se por via negocial e diplomática e por meio de intensas campanhas noticiosas e de propaganda política, agenciadas a partir do exterior, que atingem importantes sectores das elites portuguesas e de emigrados franceses refugiados no país, depois da Revolução de 1789. Começando pela questão da propaganda, assinalamos a criação do Cercle Social, que, segundo informa o embaixador português em Paris, Vicente de Sousa Coutinho, tinha por objectivo difundir nos países europeus e nos domínios americanos a doutrina revolucionária. Ao abrigo do Cercle Social teriam partido, em 1791, do porto de La Rochelle com destino a Portugal Pierre Choderlos de Laclos, autor do célebre livro Les Liaisons Dangereuses, acompanhado de três jacobinos franceses. Regista ainda o mesmo embaixador que tivera notícia da edição traduzida da Constituição de 1791, com uma tiragem exorbitante, de 12000 exemplares, a cargo de Diogo Borel, destinada também ao mercado português, assim como de milhares de catecismos revolucionários, um dos quais conhecido pela designação de folha do "Père Gerard". Entretanto, em Janeiro de 1793, é preso Francisco Coelho da Silva acusado de ter redigido uma Censura à Constituição Franceza e de ter traduzido a Declaração dos Direitos do Homem e do Cidadão. Pina Manique vislumbrava o perigo da actuação de Coelho da Silva em função da natureza interclassista da recepção da sua mensagem. Segundo o Intendente Geral da Polícia, "ele se introduzia entre varias qualidades de gente, que talvez por gostarem de o ouvir, tinha a facilidade de o admitirem em suas casas" (Soriano, t.I, 1866: 404).

No quadro de iniciativas avulsas ou concertadas de internacionalização dos ideários políticos em confronto depois da Revolução, as movimentações de agentes e emissários estrangeiros em Portugal tornam-se motivo de redobrada vigilância por parte da Intendência 
Geral da Polícia. A mando de Pina Manique é preso, em 1791, no Porto de Lisboa, para identificação e inquirição, Luís António Martins Calhassen, oriundo da região do Languedoc, que chega a Lisboa com o cargo de secretário da embaixada de França. Porém, as credenciais de que era portador não foram reconhecidas pelo embaixador francês, conde de Châlons.

Entre outros indivíduos de incerta condição e de suspeita ligação aos revolucionários de Paris encontrava-se Thomas António Lequens que, ao desembarcar em Lisboa, se fez passar por familiar de comerciantes com o mesmo apelido estabelecidos na capital portuguesa. Em relação a outros emissários e agentes estrangeiros de passagem pela capital portuguesa, como Kerc e Fontaine, havia suspeitas fundadas de que os contactos com os revolucionários se realizavam por intermédio de mensageiros bem colocados em Badajoz e Madrid (Ramos, 2007: 178).

Entretanto, os esforços propagandísticos de Convenção, depois da criação, em 1793, de Comités Espagnols d'Instruction Publique, em Bayonne e Perpignan, tiveram também alguma repercussão em Portugal. Antes de ter início a campanha do Roussilhão (1793-195) - que levantou o exército espanhol auxiliado por um destacamento de tropas portuguesas contra o expansionismo da república francesa - circularam clandestinamente, em Espanha e Portugal, versões traduzidas das Constituições de 1791 e 1793 e da Declaração dos Direitos do Homem e do Cidadão, para além de inúmeros jornais estrangeiros, folhetos e catecismos revolucionários, como o famoso "Credo da República Lombarda", apreendido pelo corregedor da comarca de Barcelos, em 1797, a um advogado da terra e que começava assim: "Creyo na Republica Francesa huna e indevizivel creadora da igualdade e liberdade, no general Bonaparte, seu filho nosso único defensor"1.

Com o mesmo nexo republicano, também em Coimbra fora afixado, na Porta Férrea, um pasquim contra um dos ministros de D. João, José Seabra da Silva, e contra a monarquia, e que continha referências como esta: "o velhaco vil Seabra aos pés calquemos/ De vós os monstros tremão, trema o Trono, / Que hum dia o Trono, tudo arrazaremos"2. A esta acção revolucionária de rua, para utilizar uma expressão moderna, estiveram ligados os estudantes Alexandre Inácio Correia Soares Velho, Francisco Simões Magiorchi e outros nomes não identificados. Estes jovens desordeiros tinham elementos de ligação na capital, pois, no mesmo ano de 1797, no cais de Santarém, foram ainda apreendidos papéis sediciosos manuscritos da mesma autoria, papéis que, segundo o corregedor da comarca, tinham por objectivo "revoltar os povos e mostrar a occasião que devem aproveitar para este fim, atacando o tribunal do Santo Officio, os seus ministros e o que he mais até o Príncipe"3.

\footnotetext{
1 ANTT, Ministério do Reino, maço, 454, caixa 569. A abreviatura utilizada nesta nota e nas seguintes corresponde ao Arquivo Nacional da Torre do Tombo.

${ }^{2}$ ANTT, Ministério do Reino, maço 454, caixa 569.

${ }^{3}$ ANTT, Ministério do Reino, maço 454, caixa 569.
} 
Os sinais de tensão social e de contestação política, mais sensíveis em praças, cafés e locais públicos da capital, conforme se colige da documentação da Intendência Geral da Polícia relativa aos anos noventa do século XVIII, propagam-se também ao Porto, onde, em 1794, são borrados editais e pastorais afixados em paredes de edifícios públicos (Dias,t. I,1980: 367)

Com o passar dos anos, os motivos de suspeição e denúncia estendem-se a cidadãos e agentes da embaixada da França e até a emigrados tradicionalistas, com residência em Portugal. Os livreiros Borel, Bertrand, Aillaud, Dubié, Loup e outros, são acusados, em diferentes momentos, de subverterem a ordem pública, vendendo livros proibidos. Entre a burguesia francesa, com sólidos negócios no reino, ressaltam pela simpatia que publicamente manifestaram aos ideais da Revolução, os industriais Jacôme Ratton e Lécussan Verdier, o cravador de diamantes Louis Madry e os pintores Pierre Noel e Nicolas-Louis Delerive, entre outros nomes menos conhecidos (Ramos,1979).

No grupo dos emigrados franceses prevalecem, todavia, os aristocratas conservadores anti-republicanos, como o conde de Coigny que representa oficialmente na corte o conde da Provença, futuro Luís XVIII; o conde de Vioménil que substitui, temporariamente, o prussiano conde de Goltz á frente do comando do exército português; o marquês de Toustain que o regente nomeou tenente-coronel de cavalaria; o conde de Novion comandante da Guarda Real de Polícia e muitas outras figuras da nobreza e do clero protegidas, durante a Convenção, pelo embaixador francês, conde de Châlons, que chegou mesmo a colaborar com a Intendência Geral da Polícia, denunciando compatriotas seus, estabelecidos ou de passagem em Lisboa, acusados de jacobinismo.

No seio do grupo de emigrados franceses, os intelectuais moderados exilados e, em especial, os membros da igreja galicana que recusaram jurar a constituição civil do clero contaram com apoio expresso dos principais membros do episcopado português. Calcula-se que em Espanha se refugiaram 5000 eclesiásticos franceses, muitos dos quais tiveram como último destino Portugal (Chaves, 1984: 46). Aqui distribuíram-se pelas várias dioceses do reino, hospedaram-se em conventos e foram acolhidos pela fidalguia de província e pelas melhores casas aristocráticas, servindo como preceptores e mestres de meninos.

D. Francisco de Almeida Portugal, conde de Lavradio, nas suas Memórias, lembra que começara a "estudar a língua francesa com um eclesiástico francês, que tinha sido cónego de Santa Genoveva, em Paris, chamado Doisseau ou Doissot", e que, pouco depois, tivera como professores "primeiro o abade Boiret, vendeano, e depois o abade Laloir, natural de Arras, ambos eles emigrados" (Lavradio, I, 1932: 13).

Um outro testemunho desse tempo encontra eco no manuscrito de exílio, sem atribuição de autoria, mas escrito com toda a probabilidade por um clérigo, intitulado: "La mort de Louis Seize et de Marie-Antoniette, Roi et Reine de France, ou Tableau historique 
de l'origine et des progrès de la Révolution". Neste texto, as atrocidades e os excessos dos revolucionários eram justificadas pelo "fanatisme irreligieux et philosophique" que grassava em França e que se propagava vertiginosamente, ameaçando as monarquias europeias e pondo em perigo a conservação dos domínios coloniais das potências marítimas ocidentais. De acordo com esta leitura política:

le feu de la Révolution n'embrasait pas seulement la France. II avait franchi les limites des mers. Les torches ensanglantées de la discorde avaient pénétré dans les colonies, allumées et portées par les émissaires de l'Assemblée. Elles y faisaient les plus cruels ravages (Brito, 1989: 309).

Para além da protecção institucional de que gozavam os mais influentes membros da colónia francesa emigrada em Portugal, o governo de Londres garantiu apoio financeiro e diplomático a muitos dos servidores aristocráticos franceses colocados, temporariamente, ao serviço da Corte de D. Maria I. Mesmo gozando desta dupla protecção, a maioria dos membros da comunidade francesa acabou por abandonar o país antes da guerra, um outro grupo menor alistou-se no chamado "exército dos príncipes", e uma parcela residual ficou ao serviço da monarquia. Em 1798 os regimentos de emigrados e as forças inglesas que se encontravam em Portugal ascendiam a 5732 homens, isto é, representavam cerca de um quarto de todos os alistados de primeira linha (Chaves, 1984: 55).

Depois da iniciativa do $1^{\circ}$ cônsul, Napoleão Bonaparte, de amnistiar muitos dos que se haviam exilado, e na sequência da assinatura da Concordata (1801) com a Santa Sé, o clero e a nobreza expatriados puderam livremente regressar a França (Boudon, 2006). Portanto, a colónia de emigrados franceses em Portugal foi diminuindo, em número e importância. Os nobres e oficiais incorporados no exército português que ficaram colaboraram efectivamente com Junot, antes e durante a ocupação militar francesa. E depois da rendição das forças de ocupação e da assinatura da Convenção de Sintra (30 de Agosto 1808) muitos acabaram por regressar a França, também amnistiados.

Em relação à embaixada francesa, desde o tempo em que o conde de Châlons a dirigiu com manifesta parcialidade até à missão impossível, em 1805, do embaixador JeanAndoche Junot em Lisboa, alguns motivos de pública denúncia acabaram por converter-se em incidentes graves, do ponto de vista diplomático. Retemos apenas dois episódios que resumem o carácter dúplice da actuação da embaixada francesa antes da guerra. $O$ primeiro incidente prende-se com a perseguição movida ao emissário diplomático da Convenção Antoine Darbault. De Março a Abril de 1793, o republicano Darbault viveu a salto em Lisboa, acabando por ser repatriado num navio que viria a ser apresado pelos ingleses. 
O segundo incidente grave ocorre com a embaixada do general Lannes (1802-1804), um militar de carreira, que participou nas campanhas de Itália e do Egipto, que tomou parte activa no golpe de 18 de Brumário (9 de Novembro de 1799) e que é destacado para Lisboa em 1802, ano da assinatura da Paz Geral de Amiens, para cumprir uma verdadeira missão ofensiva em termos diplomáticos. Depois de alguns conflitos com membros do governo, Lannes exige e consegue obter o afastamento de Vioménil do comando do exército português e a demissão do Intendente Geral da Polícia e da Alfândega Pina Manique (Março de 1803). Conhecedor das intrigas da corte, da crise financeira do Estado Português, dos planos de transferência da família real para o Brasil, Lannes negoceia vantagens para comércio externo do seu país e garante o pagamento à França de avultadas contribuições de guerra por parte de Portugal.

Depois da proclamação do Império, em 1804, a hegemonia militar francesa no continente conduzirá à abertura de uma frente militar na Península lbérica, frente que, no caso português, foi meticulosamente preparada no plano diplomático. Um cabo-de-guerra, um ex-ajudante de campo de Napoleão, o general Jean-Andoche Junot é nomeado, em 1805, embaixador em Lisboa. O homem que vinha preparar a investida militar de 1807, por sinal por ele dirigida, trazia credenciais alargadas, de tal modo que arriscou contar espingardas antes da guerra, isto é, negociou apoios, certificou-se das clivagens internas na corte, das quebras de fidelidade dos Grandes em relação à realeza, da simpatia da elite mais politizada à causa do continente, encontrou um grupo interessado na tradução do Código Civil de 1804 e estabeleceu uma rede contactos no seio das mais influentes instituições do reino.

Napoleão que se dirigia por carta a Dom João utilizando os epítetos de "muito amado Irmão e Primo, aliado e confederado", garantira previamente que o seu último embaixador em Lisboa iria ser recebido, em solene audiência, por um príncipe "enfeitado com um dos sete grandes cordões da Legião de Honra que o imperador lhe enviara", como regista Jacôme Ratton. Idêntico agraciamento receberam os duques de Cadaval e de Lafões e os ministros conde de Vila-Verde e António de Araújo de Azevedo (apud Gotteri, 2006: 122). Em suma, à medida que a tensão bélica no continente aumentava a corte portuguesa espelhava a protecção do Império, garantindo uma suposta "neutralidade" internacional e aceitando, tacitamente, proteger a França e os seus cidadãos.

A este compromisso de honra e de palavra correspondeu, pouco depois, D. João ao recusar declarar guerra ao exército ocupante franco-espanhol. Sete dias depois de este ter cruzado a fronteira, em 19 de Novembro de 1807, um edital régio ordenava que as autoridades locais e os agentes do poder central recebessem os franceses como amigos e protectores. 
De facto, a força de ocupação dirigida por Junot progrediu lentamente no território nacional sem enfrentar resistência armada organizada. $O$ general francês apresentou-se como 'protector do reino', foi bem acolhido pelos membros do Conselho de Regência, recebeu cumprimentos oficiais da Guarda Real de Polícia e da Academia das Ciências, foi saudado por membros da Maçonaria e pela hierarquia eclesiástica e instalou o seu quartelgeneral em Lisboa. Procedeu a pequenas alterações na composição do executivo e instituiu um governo de protectorado, de molde a salvaguardar a capacidade de exercício das autoridades portuguesas.

A "submissão" dos governadores do reino e das mais altas dignidades eclesiásticas ao regime imposto por Junot correspondeu, em termos práticos, à concretização do plano táctico adoptado pelo príncipe regente $\mathrm{D}$. João antes da partida da corte para o Brasil, plano que teve o aval de Inglaterra. Em representação do poder absoluto, a Regência acatou e cumpriu, escrupulosamente, as orientações do ministério sediado no Rio de Janeiro. De Novembro de 1807 a Junho de 1808, colaborou abertamente com os emissários de Napoleão.

\section{A Ocupação Político-Militar e o 'Momento Constitucional' Napoleónico}

Em 1 de Fevereiro de 1808 é extinto o Conselho de Regência e Napoleão, em clara violação do Tratado de Fontainebleau, destitui a Casa de Bragança e passa a reinar oficialmente em Portugal. Só a partir de Junho, quando é conhecido em Lisboa e em todas as capitais europeias o Manifesto e exposição fundada de $D$. João $\mathrm{VI}$, e quando já se fazem sentir, do outro lado da fronteira, os ventos da revolta, a elite de poder muda de aliados e, em estreita colaboração com as massas populares, "dirige" a revolta contra o ocupante estrangeiro. A primeira aliança, congeminada com espírito de traição, evidencia a convergência táctica e a coesão ideológica das classes dominantes. "Nesta conjuntura, o colaboracionismo contribuiu para proteger e manter actuantes as instituições do Antigo Regime" (Araújo, 1985: 21).

Não deve portanto estranhar-se que uma embaixada constituída por catorze personalidades representativas das mais importantes instituições do país - Governo do Reino, Inquisição, Universidade, Senado da Câmara de Lisboa, Ordem Militares e Junta dos Três Estados - se tenha dirigido a Bayonne para cumprimentar, em nome da nação portuguesa, o imperador dos franceses. O encontro com a "deputação portuguesa", apesar de inconclusivo, ocorreu em Abril de 1808. A iniciativa desta missão partiu do poder francês que negociou com os elementos que compunham a representação os termos do pacto de aceitação do poder imperial em Portugal, termos flexíveis se tivermos em conta que, 
oralmente, se propôs que a dinastia de Bragança fosse reintegrada nos seus direitos, isto é, que continuasse a reinar (Ramos, 1983; Hespanha, 2008).

Acompanhando as movimentações destes afrancesados com mandato político de Junot, mas temendo a inércia das instituições políticas e o desfecho dos motins protagonizados pelos de mais baixa condição que começavam a surgir, os ilustrados e os liberais que se colocaram do lado da França acabaram por trilhar uma outra via, mais imediata e viável para a materialização de um vasto programa de reformas institucionais e económicas. Unidos à causa continental, resolveram peticionar, de motu proprio, ao imperador uma Constituição para Portugal.

Para além da confirmação das intenções reformistas de Napoleão em relação a Espanha, teve algum impacto no desencadear da petição constitucional destes afrancesados portugueses a intenção expressa pelo imperador de fazer vigorar em Portugal o Código de Direito Civil de 1804. Esta ideia, aliada à proposta de secularização de metade dos bens dos conventos, foi saudada com entusiasmo por este grupo. Todo o processo que envolveu a iniciativa da tradução, a escolha do tradutor e a impressão final do Código foi depois cuidadosamente silenciado e, por isso, ainda hoje se conhece mal. De qualquer modo, não deixa de ser surpreendente que entre a primeira indicação vinda de Paris nesse sentido e a resposta do general Junot, que dava a obra concluída e em vias de publicação, medeie pouco mais de uma semana ${ }^{4}$. A cronologia dos acontecimentos [respeitantes à tradução do Código] permite concluir que a ideia de imposição do código é anterior à proposta de Napoleão e que o projecto inicial e a sua concretização se inscrevem, talvez, na acção subterrânea desenvolvida por alguns afrancesados durante a embaixada de Junot em Lisboa, entre os anos de1805 e1806.

Integravam o grupo afrancesado que defendia a outorga Napoleónica de uma Constituição para Portugal o médico Gregório José de Seixas, Ricardo Raimundo Nogueira, reitor do colégio dos nobres, Simão Cordes Brandão e Ataíde, professor de direito canónico na Universidade de Coimbra e Bento Pereira do Carmo, juiz de fora em Ançã e outros jurisconsultos. Tiveram igualmente papel de relevo na dinamização do grupo pelo menos dois franceses: o oficial Henri Carrion d'Espagne Nisas e o influente industrial de Tomar Timóteo Lecussan Verdier.

Em face do ficou exposto resta saber em que termos foi formulada a súplica dirigida a Napoleão? Que paradigma constitucional foi adoptado? Que mecanismos de legitimação

\footnotetext{
${ }^{4}$ A carta de Napoleão data de 15 de Maio de 1808 e a resposta de Junot é escrita a 24 de Maio. A respeito desta missiva, não deixa de ser curioso notar que o general francês, depois de desaconselhar a introdução do direito civil napoleónico em Portugal, acrescente: "Prevoyant bien les intentions de V. M., j'avais demandé la traduction de ces differents codes: le code de procédure civile est déjà à l'impression; le code de Commerce est traduit; on s'occupe de traduire les autres, et je les ferai imprimer sur le champ, et répandre dans le pays, les jurisconsultes feront leurs réfléxions ; quelques uns s'y attendent déjà". Je crois que la réduction dês Couvents pourra s'opérer sans de grandes difficultés, ce sera cependant une des choses les plus délicates à faire dans ce pays". (apud Sepúlveda, XII, 1917: 201-202).
} 
se previam? E que relação estabelecer entre o grupo que, em Lisboa, apresentou a "súplica constitucional" e a famosa deputação mandatada por Junot para, em Bayonne, junto de Napoleão, exprimir o voto da nação portuguesa?

A petição constitucional foi suportada por uma instituição corporativa de base representativa, a Junta dos Três Estados, que havia sido criada depois da Restauração de 1640 para administrar impostos militares. A sua reactivação em 1808, num momento em que é lançada uma pesada contribuição de guerra, de 40 milhões de cruzados, tinha também subentendido o parecer de redução daquela exacção fiscal, voto formulado directamente pelos representantes portugueses a Napoleão, em Bayonne.

Em sessão de Junta, o juiz do povo apresentou então o documento em que se pedia a conservação do reino, um rei da família imperial e uma constituição política "que fosse em tudo semelhante à que o imperador havia outorgado ao Grão-Ducado de Varsóvia, "com a única diferença de que os representantes da nação sejam eleitos pelas câmaras municipais a fim de nos conformarmos com os nossos antigos usos", conforme se diz (Araújo, 1985:75).

O paradigma moderno remete para a Constituição napoleónica do ano VIII, conjugando, porém, o propósito de mudança política com a tradição municipalista portuguesa e com a História recalcada da fundação do reino portucalense. Neste ponto, os autores da "súplica constitucional" recordavam, com manifesta parcialidade, serem os portugueses "de raça francesa, como descendentes dos que conquistaram este belo país aos mouros [...] que deve[iam] à França, sua mãe pátria, o benefício da independência que recobraram como nação em 1640". Esperavam assim que, sob a protecção do imperador, Portugal pudesse integrar-se, de pleno direito, no "sistema continental da família europeia" (Araújo, 1985: 75).

Deste diálogo entre tradição e modernidade no plano constitucional permaneceu o corpo de princípios e direitos que matizou, no essencial, o constitucionalismo monárquico português do século XIX, de filiação cartista (Catroga, 2010).

A "súplica de 1808" erigiu como princípios fundamentais do Estado de direito a igualdade civil e fiscal, a liberdade de opinião e de imprensa, o direito à propriedade, o direito à instrução e a liberdade de cultos. Em matéria de liberdades, direitos e garantias, contemplava, expressamente, a supressão da escravatura, a extinção dos bens de mão morta e a abolição de privilégios testamentais, respeitando-se estritamente o Código Civil Napoleónico.

No plano do ordenamento político, propunha a criação de um ministério da instrução pública e a separação dos três poderes (executivo, judicial e legislativo). O poder legislativo ficaria a cargo de duas câmaras, sendo exercido em "concorrência da autoridade executiva". Recorde-se que a atribuição do poder legislativo a duas câmaras foi acolhida na Carta 
Constitucional de 1826 e na Constituição de 1838, assim como o primado da outorga régia sobre a acção do poder de uma assembleia constituinte.

A "súplica constitucional" de 1808, salvaguardava a independência do poder judicial, - princípio da responsabilidade ministerial e apontava para uma reforma políticoadministrativa à francesa, mas em que as colónias portuguesas, tomadas como parte integrante do reino, fossem "consideradas como províncias ou distritos". Do ponto de vista das relações entre o Estado e a Igreja, propunha a adopção de uma religião de Estado: a Católica Apostólica Romana. No respeito pela concordata celebrada entre Napoleão e a Santa Sé (1801), garantia, no entanto, a liberdade religiosa e de culto público a todos os outros credos, o que, entre nós, só viria a acontecer depois da implantação da República, em 1910.

Em síntese, os direitos, liberdades e garantias que deviam constar de uma carta constitucional, elaborada nos mesmos moldes da que Napoleão outorgara ao Grão-Ducado de Varsóvia, compaginavam-se, como vimos, com a exigência de aplicação do Código Civil francês. Outra nota importante é a de que a renúncia da via revolucionária assentava no pressuposto de que as mudanças em curso deveriam ser conduzidas pela elite afrancesada. Esta tentativa de precipitar a mudança por meio da adopção de um constitucionalismo moderado, imposto a partir de cima, punha em causa as estruturas do Antigo Regime e as bases tradicionais da monarquia portuguesa, mas não a concepção orgânica de nação.

Partindo do modelo de constitucionalização assente num acto de outorga que, na ordem política, se sobrepunha ao direito de conquista, os afrancesados constitucionais alavancavam o princípio da representação na organização concelhia, ou seja, no poder de representação dos concelhos que, de acordo com a tradição, tinham assento em Cortes. O envolvimento histórico-constitucional dos concelhos na construção do Estado de direito a outorgar por Napoleão começou por ser caucionado pela divulgação oficial a todos os municípios do país da "súplica constitucional" e da carta enviada pela "deputação de Bayonne". Em Maio de 1808 são muito significativas as actas de vereação das câmaras municipais nortenhas que, em louvor da "benevolência de Napoleão, registam a tomada de conhecimento e a suposta adesão dos povos às reivindicações de mudança política avançadas por outros representantes da nação (Capela, 2008).

Como recentemente sublinhou Fernando Catroga, muitos dos propósitos enunciados em 1808 estiveram no centro do debate político português do século XIX, (Catroga, 2010: 36-38). As ideias defendidas em 1808 eram patrióticas e de alcance revolucionário, ainda que desprovidas dos alicerces representativos que o liberalismo acabou por consagrar. Quando surgiram foram rejeitadas, eram demasiado avançadas, postulavam a abdicação da casa de Bragança e foram mal vistas pelos sectores tradicionais, não pelo mesmo motivo, pois havia uma facção da nobreza que apoiava as aspirações de Junot à Regência do reino, 
mas porque subentendiam a abolição de ancestrais privilégios. Representado pelo conde da Ega e seus seguidores, um importante sector da nobreza aderiu à concepção ordeira do regime bonapartista, encarando-o mais como conciliador dos antigos e dos modernos, do que como continuador da revolução de 1789.

Não sendo assim os afrancesados um grupo coeso sobre eles impendia a frequente acusação de dissenso e traição. Portanto, depois da expulsão dos invasores era preciso lavar a face e salvaguardar a honra, o que mais uma vez aconteceu de forma impessoal e ao mais alto nível.

A Convenção de Sintra, ao regular as condições de evacuação do exército invasor, previra, no seu artigo XVII, que nenhum cidadão seria considerado responsável, ou seja, que nenhum português responderia autonomamente pela sua conduta política, durante o tempo de ocupação francesa. Aqueles que continuaram no exercício dos seus empregos, ou que serviram o governo francês, seriam mesmo protegidos pelos comandantes britânicos. Admitia-se que não tinha sido da sua livre escolha obedecerem ao governo francês, por isso não seria lícito causar dano a suas pessoas e propriedades.

No entanto, durante a ocupação do Porto por Soult, em 1809, os afrancesados e as elites esclarecidas daquela cidade procuram retomar, dentro do modelo constitucional bonapartista, as propostas anteriormente defendidas de transformação do Estado e da sociedade. A discussão sobre a ilegitimidade da casa de Bragança à coroa portuguesa é agora discutida abertamente, com o argumento de que a fuga da Corte para o Brasil significara, em termos práticos, a abdicação do ceptro português. Recorde-se que a ideia de violação do pacto político, entre o monarca e os seus súbditos, já havia sido denunciada pelo juiz do povo, José de Abreu Campos, por ocasião da reunião da Junta dos Três Estados. Na presença de Junot, a vacância do trono português tinha sido discutida não em termos de direito mas em termos de facto, pois o juramento de obediência e fidelidade fora firmado com a rainha Dona Maria, ainda viva. Na ausência da realeza, cabia ao povo, representado pelos seus procuradores em Cortes, verificar se Dom João, ao partir para o Brasil, violara ou não as leis fundamentais do reino. É que a ideia de um rei manietado e enganado pelos seus ministros não garantia a perenidade do seu governo.

Retomando esta questão, vem a público, em 1809, o Desengano proveitoso que um amigo da pátria se propõe dar aos seus concidadãos (1809), texto atribuído a Frei António de Santa Bárbara. O seu autor pronuncia-se em nome da pátria e em defesa da soberania nacional e avança novos argumentos a favor da liberalização do regime político em Portugal, sustentando a inevitabilidade da queda do absolutismo, o carácter usurpatório da protecção inglesa e a derrocada do partido dos áulicos em Portugal.

A ideia de que o reino fora confiado a um "governo cobarde e inepto", "composto de fidalgos que aprenderam a política entre divertimentos de jogo e de caça", reforçava a 
conviç̧ão de que o príncipe [com o abandono do reino] "renunciou, espontaneamente, o direito à Coroa de Portugal". Deste modo, a defesa do princípio da "vagatura do trono português" e a consideração da existência de um "governo fanático, ilegal e nulo" suscitam a discussão da legitimidade da soberania política. Na linha do abade de Sieyes, o autor do Desengano proveitoso que um amigo da pátria se propõe dar aos seus concidadãos postula, assim, a possibilidade de a nação poder assumir-se politicamente como sujeito constituinte, a partir do primado conferido ao contrato social. O objectivo é alicerçar a nação no império da lei, entendida esta como expressão da vontade geral, conforme o modelo francês de 1789. Neste sentido, escreve:

As leis fundamentais da monarquia não permitem que o príncipe trespasse a coroa a sujeito da sua amizade. Se o príncipe legítimo existe governe ele; se não existe, a coroa cai de novo na mão dos povos, que, sós, a podem dar a varões prestantes. Em toda a parte a soberania não é património particular dos príncipes, mas um depósito sagrado que se Ihes confiou para promoverem e não arruinarem a fortuna pública (apud Dias, II, 1980: 507).

De forma mais enfática do que em 1808, o discurso político afrancesado ganha um leve acento republicano, na forma como equaciona o superior interesse público. $\mathrm{A}$ linguagem da moderna cultura política afrancesada, indissociável da expressão da vontade geral através da opinião pública, alicerça-se no confronto de pareceres doutrinalmente fundamentados sobre o Estado e os direitos da realeza e encontra eco nos espaços e meios que funcionam como grandes mediadores da modernidade política: os periódicos e a imprensa em geral, os clubes, as associações e as lojas maçónicas.

À margem dos mecanismos de imposição de uma opinião pública refractária ao regime, a leitura oficial dos diferentes processos de afrancesamento das elites portuguesas distancia-se, simultaneamente, da perspectiva histórica de José Acúrsio das Neves. Este autor, realista e conservador, não isenta de responsabilidade política algumas das mais altas dignidades, eclesiásticas e civis que, a mando de Junot, se deslocaram a Bayonne, para saudar Napoleão. Desconfia das intenções patrióticas reclamadas por alguns membros que integraram a deputação e considera mesmo hostis e antipatrióticas outras manifestações ideológicas subsequentes de adesão ao bonapartismo (Araújo, 2008).

Recorde-se que na época, as palavras pátria e patriota e os seus antónimos eram recorrentes no discurso político. Em geral, o patriotismo traduzia as mais legítimas aspirações de libertação colectiva, de filiação e de pertença a um destino comum, de ordem e de fidelidade. Para a maioria, a pátria comum, no sentido étnico-religioso e histórico, tinha a sua expressão mais elevada na aliança do povo à religião e ao rei. Para o escol político 
afrancesado a pátria comum, ou seja, " o sistema continental da família europeia”, fundavase no império da lei e na aspiração futurante da liberdade, com raízes míticas no passado, na fundação do reino, tal como se reivindicava.

Num campo como noutro, existiam patriotas, homens que pautavam, com abnegação e virtude, a sua conduta por modelos ético-políticos diferentes. Por isso, o termo patriota tanto era usado para caracterizar a lealdade e a bravura de elementos anónimos do povo que se singularizavam em campanhas de resistência contra o invasor, como para exprimir a singularidade das acções de indivíduos civis ou religiosos com poder de representação, fiéis às leis da res publica e aos ideais da "pátria cívica", à maneira da Revolução Francesa.

$\mathrm{Na}$ esteira de Fernando Catroga, pensamos que o primeiro nível de patriotismo tem uma forte componente comunitarista, componente essa que se pode articular com a escolha livre dos cidadãos, ou seja, com um patriotismo

polarizado, dominantemente, por valores jurídico-políticos, perspectiva que, reactualizada, virá a ser fundamentadora da ideia de patriotismo cívico de raiz contratual e, por extensão e transformação, do conceito moderno de 'nação cívica'. Por sua vez, embora a primeira acepção pudesse coabitar com a segunda, elafuncionará, sobretudo, como o molde por excelência, quer da concepção mais holística, étnico-cultural e territorial dos sentimentos de pertença, quer da sua expressão mais totalizadora como "nação orgânica" (Catroga, 2008: 13).

Os alicerces da concepção de nação orgânica são, por seu turno, indissociáveis da visão histórica da guerra. No relato histórico que José Acúrsio das Neves construiu das Invasões Francesas, nota-se que o pathos emocional da revolta sublima a virtude do povo e o horror causado pelo impacto brutal e sangrento da chacina perpetrada a gente inocente e totalmente desprotegida. Reportando-se ao fuzilamento ocorrido em Leiria, no sítio da Portela, a 5 de Julho de 1808, fala da "mais horrível carniceria" de que havia memória, concentrando o seu olhar na aflição provocada pela violência armada e na irremediável reparação de dois sobreviventes (Araújo, 2010).

Magistral na construção visual de uma execução de guerra, convertida em martírio para um sobrevivente, escrevendo sem artifício e utilizando apenas a emoção e a naturalidade para exprimir os acontecimentos, Acúrsio das Neves coloca os heróis e as vítimas das Invasões Francesas, sem distinção de hierarquia, estado ou condição, no mesmo pedestal. O seu lema é claro: "os libertadores da pátria são dignos de recomendarse ao reconhecimento do soberano e da nação, e os seus nomes de serem transmitidos à posteridade com a glória que Ihes é devida" (Neves, t. I, 1984:143-144). 
Do ponto de vista da memória, o ardente patriotismo do autor que seculariza e dessacraliza a História é o mesmo que confere um toque martirológico aos heróis da narrativa. Esta "transferência de sacralidade" (Ozouf, 1976) funciona como garantia de segurança para os sobreviventes e como cenário ideal para o aparecimento de novos cultos cívicos, em torno dos mártires da liberdade e dos heróis da guerra, que tardaram, no entanto, a impor-se em Portugal.

$\mathrm{Na}$ verdade, no termo da guerra, foi duplo o silêncio que se abateu sobre os acontecimentos e os seus reais protagonistas: perseguidos, clandestinos, mortos, sobreviventes e desaparecidos. Muitos dos arautos da mudança política que em 1808 tomaram a palavra sofreram perseguições, alguns foram presos e outros deportados para Inglaterra. Dos dois lados da barricada, as vozes das elites e os actos de rebeldia do povo foram recalcados ou mesmo banidos da memória colectiva. A resistência e a insubmissão do povo indefeso significava a falência temporária das autoridades que representavam o despotismo régio e sua lembrança, nos anos seguintes, não deixava, por isso, de constituir uma provocação para os caudilhos político-militares ao serviço da Coroa.

À política da memória contrapôs-se, portanto, a necessidade de organização do esquecimento, condição essencial para que se forjasse a ilusão necessária de continuidade do poder e de perenidade da nação. A persistente linha de silêncio em que estancou e se suspendeu a evocação histórica tradicional deste período seminal da nossa conturbada e indecisa contemporaneidade tem assim escamoteado não as questões da guerra mas os problemas da difícil unidade política da resistência. 


\section{Bibliografia}

ARAÚJO, Ana Cristina (1985). "Revoltas e ideologias em conflito durante as Invasões Francesas". In: Revista de História das Ideias, vol.7, pp. 7-90.

ARAúJo, Ana Cristina (2008). "Memória e Mitos da Guerra Peninsular em Portugal. A 'História Geral da Invasão dos Franceses' de José Acúrsio das Neves'. In: Revista de História das Ideias, vol. 29, pp 241-274.

ARAújo, Ana Cristina (2010). “Ocupação e Resistência na Guerra Peninsular. O Massacre de 5 de Julho de 1808, em Leiria”. In: Revista de História das Ideias, vol. 31, pp. 151-188. BoudON, Jacques-Olivier (2006). La France et l'Europe de Napoléon. Paris: Armand Colin. BRITO, Ferreira de (1989). Revolução Francesa. Emigração e Contra-Revolução. Porto: Universidade do Porto.

CAPELA, José Viriato et. al. (2008). O Heróico Patriotismo das Províncias do Norte. Os Concelhos na Restauração de Portugal de 1808. Braga: Casa Museu de Monção/Universidade do Minho.

CATROGA, Fernando (2008). "Pátria, Nação, Nacionalismo". In: Luis Reis Torgal, Fernando Tavares Pimenta, Julião Soares Sousa (coords.). Comunidades Imaginadas, Nação e Nacionalismos em África. Coimbra: Imprensa da Universidade, pp. 9-39.

CAtroga, Fernando (2010). “Em Nome da Nação”. In: Fernando Catroga e Pedro Tavares de Almeida (coords). RES PUBLICA. Cidadania e Representação Política em Portugal, 1820-1926. Lisboa: Assembleia da República/Biblioteca Nacional de Portugal, pp. 20-59. CHAVES, Castelo Branco (1984). A emigração francesa em Portugal durante a Revolução. Lisboa: Biblioteca Breve.

DIAS, Graça da Silva e DIAS, José Sebastião da Silva (1984). Os primórdios da Maçonaria em Portugal. 1, t.Il., Lisboa: INIC.

GotTERI, Nicole (2006). Napoleão e Portugal (tradução de Paula Reis). Lisboa: Teorema. Hespanha, António Manuel (2008). "Bajo el signo de Napoleón. La Súplica Constitucional de 1808". In: Cuadernos de Historia Moderna, vol. VII, 2008, pp. 299-318.

LAVRAdIO, Conde de (1932). Memórias do Conde de Lavradio - D. Francisco de Almeida Portugal, vol. 1. Lisboa: Imprensa da Universidade.

NEVES, José Acúrsio das (1984). História Geral da Invasão dos Franceses em Portugal e da Restauração deste Reino. In: Obras Completas. Porto: Edições Afrontamento.

Ozouf, Mona (1976). La fête révolutionnaire (1789-1799). Paris: Gallimard.

Pocock, J. G. A. (1975). The Machiavellian moment: Florentine political thought and the Atlantic republican tradition. Princepton: Princepton University Press.

Ramos, Luís de Oliveira (1979). Da Ilustração ao Liberalismo. Temas Históricos. Porto: Lello \& Irmão. 
RAMOS, Luís de Oliveira (1983). "D. Francisco de Lemos e a deputação a Baiona”. In:

Estudos de História de Portugal de Homenagem a A. H. de Oliveira Marques, vol 2, Lisboa: Editorial Estampa, pp. 273-288.

RAMOS, Luís de Oliveira (2007). D. Maria I. Lisboa: Círculo de Leitores.

SepúlvedA, Cristóvão Aires de Magalhães (1917). História Orgânica e Política do Exército Português. Provas, vol XII, Lisboa: Imprensa da Universidade.

SoRIANO, Simão José da Luz (1866-1867). História da Guerra Civil e do Estabelecimento do Governo Parlamentar em Portugal. Compreendendo a História Diplomatica, Militar e Politica d'este Reino desde 1772 até 1834. Primeira Epocha, tomos. I e II, Lisboa: Imprensa Nacional. 